https://nv.nltu.edu.ua

https://doi.org/10.36930/40310310

$@ \bowtie$ Correspondence author

Article received 16.04.2021 p.

Article accepted 29.04.2021 p.

P. T. Yashchenko

UDC 630:907.11:502.72(477.84) ecoinst08@ukr.net

М. М. Корусь ${ }^{1}$, П. Т. Ященко

${ }^{1}$ Фізико-механічний інститут ім. Г. В. Карпенка НАН Украӥни, м. Львів, Украӥна ${ }^{2}$ Інститут екології Карпат НАН України, м. Львів, Україна

\title{
ЗУМОВЛЕНІСТЬ І ПРОЯВИ СИЛЬВАТИЗАЦІЇ ПОСТАГРАРНИХ ЕКОСИСТЕМ УКРАЇНСЬКОЇ ЧАСТИНИ ТРАНСКОРДОННОГО БІОСФЕРНОГО РЕЗЕРВАТУ "ЗАХІДНЕ ПОЛІССЯ"
}

\begin{abstract}
Охарактеризовано зумовленість спонтанного заліснення (сильватизації) колишніх сільськогосподарських угідь в українській частині транскордонного біосферного резервату "Західне Полісся" (ТБР), яка територіально охоплює регіон Шацького поозер'я. Тут від 1983 р. функціонує Шацький національний природний парк, якому у 2002 р. було надано статус міжнародного резервату біосфери (БР) і включено у світову мережу біосферних резерватів ЮНЕСКО як "БР Шацький". Від 2012 р. цей резерват є складовою частиною білорусько-польсько-українського ТБР. Природоохоронні і рекреаційні форми землекористування на поозер'ї тепер стали домінантними, зменшилося сільськогосподарське використання земель. Показано, що активізація процесів сильватизації постаграрних екосистем зумовлена, передусім, соціально-економічними причинами. Із зміною суспільно-політичного устрою України у 90-х роках XX ст. виникли нові економічні відносини, зокрема змінився характер землекористування. Після ліквідації колгоспів чимало орних земель у регіоні вибули 3 інтенсивного господарського вжитку, значно збільшилася площа перелогів та неужитків, які почали спонтанно заліснюватися. Припинилося сінокісне й пасовищне використання боліт і сіяних лук, сформованих на осушених болотах, що зумовило розвиток відновних сукцесій природної рослинності на колишніх угіддях. Сильватизація набула характеру важливої екологічної проблеми через значні зміни у структурі рослинного покриву Шацького поозер'я. Розглянуто прояви відновних сукцесій рослинності після припинення орного та сінокісного використання земель. Показано, що заліснення відбувається відповідно до еколого-біотичних умов регіону та історичних особливостей землекористування. Спостерігається ренатуралізація рослинного покриву на суходолі, але відбувається подальша трансформація лук і боліт, які використовувалися як сінокоси й пасовища. Сильватизація проявляється як формування або соснового рідколісся, або ж густого березняку. Найбільша кількість природного поновлення берези - до 75 тис. на 1 га - відзначена на колишніх старооранках. Формування зімкнутого деревостану на старооранках може відбутися впродовж 10-12 років, особливо за близького розташування стіни лісу. Після заліснення змінюються фізико-хімічні параметри грунтів, зокрема зменшується кислотність торфових грунтів і зменшується вміст азоту в них. Наголошено на доцільності активного збереження локалітетів рідкісних видів і рослинних угруповань у процесі спонтанного заліснення постаграрних екосистем у межах української частини ТБР.
\end{abstract}

Ключові слова: Шацьке поозер'я; перелоги; вересовища; занесення і поширення насіння; стіна лісу.

\section{Вступ}

Українська частина транскордонного біосферного резервату "Західне Полісся" територіально охоплює регіон Шацького поозер'я. У його межах за останні десятиліття відбувається швидке заліснення (сильватизація) колишніх сільськогосподарських угідь, тривають відновні сукцесії природної рослинності, що зумовлено соціально-економічними, еколого-біотичними та історичними причинами. Заліснення призводить як до ренатуралізації рослинного покриву і набуття постаграрними екосистемами рис природності, так і до подальшої трансформації лук і боліт, які використовувалися як сінокоси й пасовища $[4,5,9,10,11,13,14,17,18,19,20]$.

Природні екосистеми Шацького поозер'я набули ви- нятково важливого природоохоронного значення на міжнародному рівні. Зазначимо, що тут від 1983 р. функціонує Шацький національний природний парк. У 2002 р. парку надано статус міжнародного резервату біосфери (БР), і Шацьке поозер'я, вже як "Біосферний резерват "Шацький"", було включено у світову мережу біосферних резерватів ЮНЕСКО [13, 14, 20]. Від 2012 р. БР "Шацький" $є$ ядром української частини офіційно затвердженого міжнародного білорусько-польсько-українського біосферного резервату "Західне Полісся" (ТБР). Можна стверджувати, що природоохоронні форми землекористування на поозер'ї стали домінантними. Водночас розвиток ренатуралізаційних процесів у постаграрних екосистемах зумовлює істотні зміни у структурі природного рослинного покриву цього регіону [6,

\section{Інформація про авторів:}

Корусь Микола Миколайович, канд. біол. наук, пров. інженер, Шацька екологічна лабораторія. Email: nikkor2005@rambler.ru Ященко Павло Тихонович, канд. біол. наук, доцент, ст. наук. співробітник, відділ екосистемологіï. Email: есоinst08@ukr.net Цитування за ДСту: Корусь М. М. , Ященко П. Т. Зумовленість і прояви сильватизації постаграрних екосистем Української частини транскордонного біосферного резервату "Західне Полісся". Науковий вісник НЛтУ України. 2021, т. 31 , № 3. С. 68-73.

Citation APA: Korus, N. N., \& Yashchenko, P. T. (2021). Condition and appearance of silvatization of post-agrarian ecosystems of Ukrainian part of the Transboundary Biosphere Reserve "Western Polesie". Scientific Bulletin of UNFU, 31(3), 68-73. https://doi.org/10.36930/40310310 
10, 11, 12, 13, 17, 20]. Унаслідок заліснення збільшується площа березняків та березово-соснових деревостанів, виникає проблема подальшого використання заліснених ділянок та вилучення їх із фонду земель сільськогосподарського призначення. Заростають деревами і кущами сіяні луки, внаслідок формування деревного намету деградують рідкісні у межах ТБР рослинні угруповання (наприклад, вересовища) та локалітети рідкісних видів рослин, зокрема орхідних. Це свідчить про потребу активного їх збереження у межах української частини резервату.

Об'єкт дослідження - постаграрні екосистеми різного рівня трансформованості у межах української частини ТБР "Західне Полісся".

Предмет дослідження - методи і засоби визначення зумовленості сильватизації постаграрних екосистем, особливості іiі прояву на території досліджень, фітоценотичні аспекти відновлення природної рослинності.

Мета роботи - доповнення знань про трансформаційні процеси у рослинному покриві української частини транскордонного біосферного резервату "Західне Полісся" (ТБР), яка територіально представлена регіоном Шацького поозер'я.

Для досягнення зазначеної мети визначено такі основні завдання дослідження:

1) здійснити аналіз літератури стосовно проблеми сильватизації постаграрних екосистем у світі та в Україні;

2) розглянути природоохоронне значення території досліджень та причини активізації процесів заліснення у іiі межах

3) відобразити участь деревних порід у процесах заліснення;

4) охарактеризувати особливості сукцесій природної рослинності;

5) 3'ясувати зміни фізико-хімічних параметрів грунтів після заліснення;

6) розглянути явище сильватизації постаграрних екосистем із природоохоронних позицій.

Наукова новизна отриманих результатів дослідження - вперше узагальнено особливості заліснення колишніх сільськогосподарських угідь, що вибули 3 господарського використання, для території української частини ТБР "Західне Полісся".

Практична значущість результатів дослідження результати досліджень можна використати під час планування лісовідновних і природоохоронних заходів у межах Шацького національного природного парку та "БР Шацький".

Аналіз останніх досліджень та публікацій. У другій половині ХX ст. у світі стало відбуватися масштабне скорочення аграрного використання земель $[1,8,10]$. За період від 1961 до 2005 pp. із сільськогосподарського використання вилучено 223 млн га ріллі, сіножатей та пасовищ, що відображає глобальні зміни у підходах до землекористування. Активізувалися процеси сильватизації колишніх сільськогосподарських угідь та постагрогенне відновлення рослинності і грунтів на них Така тенденція була і в Свропі. Зокрема, через економічні причини та зміну земельних відносин у Польщі й Словаччині з інтенсивного аграрного використання було вилучено до 20 \% земель. За оцінками Д. І. Люрі із співавторами [1], В. М. Тєлєсніної [8] на початку століття тільки у Європейській частині Росії загальна площа перелогових земель, на яких розпочалося заліснення і лісовідновлення, сягала 36,3 млн га.
Із зміною суспільно-політичного устрою в Україні у 90-х роках XX ст. також виникли нові економічні відносини, зокрема змінився характер землекористування. Почастішало застосування нових форм використання земель, розпочалася переорієнтація на природоохоронні засади господарювання, активізувався розвиток сільського туризму та рекреаційне використання природних комплексів, що в економічному аспекті стало ефективнішим, ніж орна чи пасовищна форми господарювання. Водночас відбувалося й спонтанне заліснення значних площ колишніх сільськогосподарських угідь.

Матеріали та методи дослідження. Для характеристики процесів заліснення колишніх угідь, оцінення сучасного стану постаграрних екосистем та динаміки їх сильватизації виділено 6 модельних полігонів та закладено пробні площі (ПП), які охарактеризовано із застосуванням геоботанічних, флористичних, лісівничих i таксаційних методів досліджень $[3,9,15]$. У межах пробних площ здійснено облік природного поновлення дерев та заміряно їх висоти (градація 0,1 м). Успішність поновлення дерев на пробних площах визначали за шкалою М. М. Горшеніна, А. І. Швиденко [3]. Аналіз динаміки площ заліснення у межах обраних полігонів здійснено з використанням космічних знімків території Шацького поозер'я зі супутників Landsat 5 TM та Landsat 8 OLI/TIRS, отриманих упродовж 2006-2018 pp. Шацькою екологічною лабораторією Фізико-механічного інституту ім. Г. В. Карпенка НАН України. Для з'ясування змін у рослинному покриві застосовано методи порівняльної екології, екологічні характеристики рослинності уточнено методом фітоіндикації [16].

Вивчення фізико-хімічних характеристик грунтів i відображення морфологічних змін у грунтових горизонтах після припинення господарського використання проведено класичними методами грунтознавства [4]. Для оцінення впливу заліснення на зміну температури грунту і його вологості на глибині $10 \mathrm{~cm}$ застосовано прилад FOM/mts (TDR) виробництва Інституту агрофізики Польської Академії наук (м. Люблін. Зміни морфологічної будови грунтів внаслідок заліснення та погоризонтний аналіз їх фізико-хімічних характеристик розглянуто на підставі відповідних грунтознавчих методик (ДСТУ 4289:2004; ДСТУ ISO 10390:2001; ДСТУ 4287:2004 та ін.). Хімічні аналізи грунтів здійснено за стандартизованими загальноприйнятими методами [7] на сертифікованому обладнанні Поліської дослідної станції Національного наукового центру "Інститут грунтознавства та агрохімії імені О. Н. Соколовського"

\section{Результати дослідження та їх обговорення}

Після створення у 1983 р. Шацького національного природного парку на Шацькому поозер'ї відбулася переорієнтація на природоохоронне ведення сільського господарства. До складу парку були включені без вилучення землі п'яти сільськогосподарських виробничих колективів (СВК) та, науково-дослідного сільськогосподарського підприємства "Світязь". Після ліквідації СВК та колективного устрою ці землі для виробництва сільгосппродукції були передані селищним радам. Як наслідок, великі площі орних земель, особливо віддалених від населених пунктів і використання яких стало економічно невигідним, вибули з інтенсивного господарського вжитку і старооранки перетворилися на перелоги. Припинилося пасовищне використання боліт та 
сінокісне господарювання на багатьох ділянках сіяних лук, сформованих на осушених болотах. Це призвело до значного збільшення площ неужитків, на яких стали відбуватися серійні зміни природної рослинності відповідно до нових екологічних умов, що складалися в цих екосистемах внаслідок призупинення антропогенного впливу. Найбільш вираженим $є$ заліснення колишніх орних земель. Наведене свідчить, що активізація і посилений розвиток процесів заліснення перелогів зумовлені, передусім, соціально-економічними причинами, а сильватизація набула характеру важливої екологічної проблеми. Такі новосформовані лісові угруповання тепер почали називати "самосійні ліси", а проблему їх подальшого використання розглядають на державному рівні, про що свідчить трансляція по телебаченню 28 квітня 2021 р. засідання "Круглий стіл: "Потенціал заліснення та відновлення природних екосистем за умов земельної реформи".

Водночас заліснення колишніх сільськогосподарських угідь і відновлення природної рослинності $\epsilon$ типовим еколого-біотичним явищем для території ТБР, воно зумовлене природними умовами, характерними для регіону Шацького поозер'я, зокрема балансом вологи i тепла. Такий баланс характеризується гідротермічним коефіцієнтом Г. Т. Селянінова (ГТК), який відображає відношення кількості опадів до випаровуваності (Е) за період із середньодобовою температурою вище $+10^{\circ} \mathrm{C}$ (рис. 1,a).
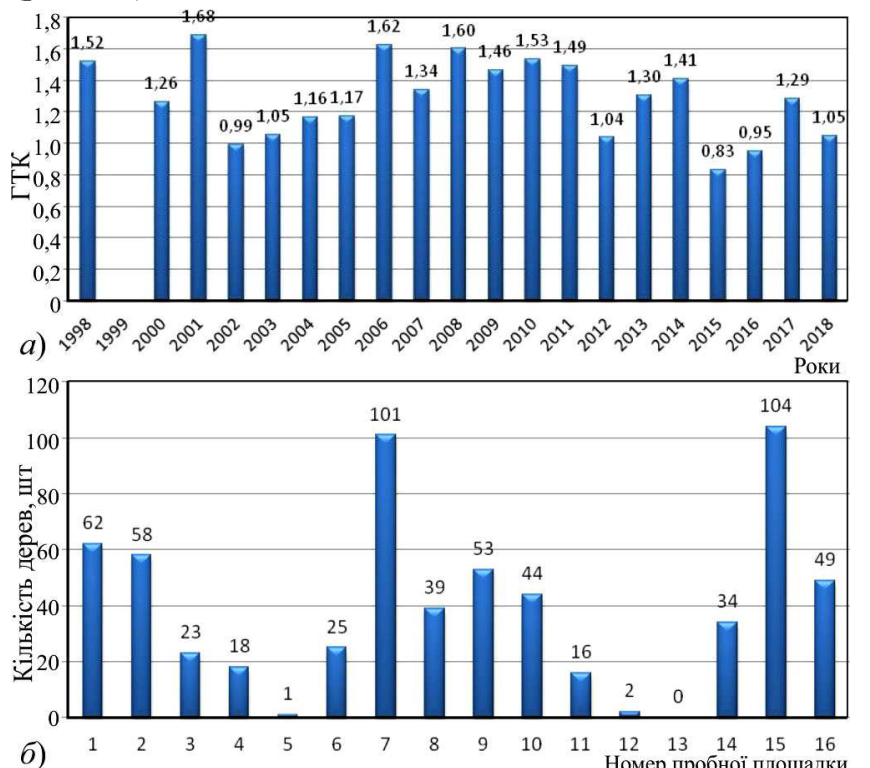

Рис. 1. Значення ГТК для Шацького поозер'я за період 1998-2018 pp. (a), розподіл природного поновлення по облікових майданчиках на пробній площі ПП6-06 (окраїна болота "Рипицьке") (б)

Середнє значення ГТК для території Шацького поозер'я за період 1998-2018 рр. становить 1,29 і характеризує територію поозер'я як сприятливу для росту лісу i його домінування у рослинному покриві.

Формування лісових фітоценозів на місці старооранок відображає також історичну зумовленість сильватизації, бо орні землі на Шацькому поозер'ї формувалися переважно на місці зрубів лісу на суходолах, і лише за останні десятиріччя - розорювали осушені болота. Заліснення старооранок відображає їх ренатуралізацію в лісові екосистеми, тоді як заліснення угідь на болотах посилює деградацію болотних екосистем. Можна ствер- джувати, що сильватизація постаграрних екосистем на поозер'ї в історичному плані проявляється у двох аспектах. Перший - це відновлення лісу на колишніх лісових територіях, які після вирубування деревостану в далекому минулому тривалий час використовувалися як орні землі, сінокоси чи пасовища, а тепер вибули із сільськогосподарського використання і поново заліснюються. Другий аспект - це формування лісу на територіях споконвічно безлісних, на яких ліс ніколи не ріс; такими $є$ колишні болота, осушені в процесі так званої меліорації і трансформовані в сіяні луки, які використовувалися як сінокоси й пасовища. I якщо у першому випадку можна говорити про ренатуралізацію екосистем, про відновлення їх природності, то сильватизація осушених боліт є проявом їх подальшої трансформації, зумовлює заміну боліт лісовими екосистемами [5, 6, 10, 19].

3'ясовано, що заліснення перелогів на суходолах i відновлення лісових екосистем у межах досліджуваної території ТБР відбувається за участі лише декількох лісових деревних порід - це береза повисла (Betula pendula (L.) Roth.), сосна звичайна (Pinus sylvestris L.), осика (Populus tremula L.), зрідка вільха чорна (Alnus glutinosa (L.) Gaertn.). С й домішка кушових видів верб (Salix cinerea L., S. purpurea L., S. nigricans Sm.). На пасовищах відзначено також участь декількох садових порід - це яблуня домашня (Malus domestica Borkh.), груша звичайна (Pyrus comunis L.), занесенню й поширенню яких сприяє худоба. Тобто у процесах сильватизації переважають анемохори, рознесення їхного насіння вітром відбувається як влітку, так і взимку по снігу (сосна), що забезпечує і дальність поширення цих видів, і значне накопичення насіння на окремих ділянках перелогів та занесення його на болота. Зоохорія більш виражена на пасовищах.

На колишніх орних землях сильватизація проявляється шляхом формування або соснового рідколісся, або ж у вологіших умовах - густого березняку, оскільки екологічні умови на перелогах сприятливі для занесення насіння сосни й берези, особливо за близького розташування стіни лісу. На узліссях домінантом деколи може виступати осика, а недавно розорані осушені болота заростають березою та вільхою, проте остання швидко випадає зі складу молодої порослі за браком достатньої для її виростання кількості вологи. За результатами наших досліджень, найбільшу кількість самосіву - від 46 до 75 тис. на 1 га - відзначено саме на суходільних старооранках $[3,11,19]$.

Для прикладу, наводимо просторовий розподіл природного поновлення на пробній площі ПП6-06, закладеній на багатих дернових грунтах поблизу болота "Рипицьке" (рис. 1,б). Ця площа з усіх боків оточена лісом, що сприяло появі тут значної кількості самосіву.

Облікові майданчики $(2 \times 2$ м) були розташовані у вигляді трансекти рівномірно (через 2 м) на всю ширину пробної площі. Проте, незважаючи на сприятливі умови для занесення насіння, самосів розподіляється по площі нерівномірно, що відображає і вплив вітру, і віддаль від стіни лісу.

Відновлення лісу (як зімкнутого деревостану) на старооранках може відбутися впродовж 10-12 років. Зміну проекційного вкриття деревною рослинністю окремих полігонів, визначену на підставі аналізу космознімків, відображає таблиця. 
Таблиця. Динаміка проекційного покриття деревної рослинності на полігонах вивчення сильватизації постаграрних екосистем

\begin{tabular}{|c|c|c|c|}
\hline \multirow{2}{*}{ Назва полігону } & \multicolumn{3}{|c|}{\begin{tabular}{|} 
Проекційне покриття (\%) деревної \\
рослинності на полігонах за роками
\end{tabular}} \\
\cline { 2 - 4 } & 2006 & 2015 & 2018 \\
\hline $\begin{array}{c}\text { "Кулевицьке" - колиш- } \\
\text { ні орні землі }\end{array}$ & 33 & 35 & 88 \\
\hline $\begin{array}{c}\text { "Дубовець" - колишні } \\
\text { сінокоси та випаси }\end{array}$ & 15 & 34 & 74 \\
\hline $\begin{array}{c}\text { "Колеса" - колишні ор- } \\
\text { ні землі та випаси }\end{array}$ & 10 & 17 & 64 \\
\hline $\begin{array}{c}\text { "Рипицьке" - окраїна } \\
\text { болота }\end{array}$ & 15 & 24 & 88 \\
\hline
\end{tabular}

На осушених болотах формування лісу відбувається переважно завдяки березі, насіння якої масово заноситься вітром у червні-липні. На колишніх сінокосах численність поновлення перебуває в межах 10-11 тис. особин на 1 га, причому воно зазвичай $є$ старшим від старооранкового, бо не всі ділянки трав'яних боліт викошували щорічно. Відзначимо також, що припинення сінокосіння сприяє відновленню участі колишніх болотних трав-гігрофітів у формуванні рослинності за рахунок довголітнього збереження діаспор таких видів. Спостерігається посилена конкуренція лісових і болотних видів, що проявляється у формуванні березняків сірувато-куничникових. Навіть у 30-річному березняку у наземному вкритті домінує куничник сіруватий (Calamagrostis canescens L.) - до 90 \% проекційного покриття, трапляються такі гігрофіти, як мітлиця повзуча ( $A g$ rostis stolonizans Bess.), ситник розлогий (Juncus effusus L.), вербозілля звичайне (Lysimachia vulgaris L.), очеретянка (Phalaris arundinacea L.) тощо. Це свідчить про довготривалість формування лісу на болотах, про стійкість болота як екосистеми навіть за значної іï трансформації і зміни вихідних екологічних параметрів [20].

Припинення використання сільськогосподарських угідь, як щорічного трансформаційного антропогенного впливу на функціонування угідь, із біотичних позицій означає зникнення регулятора конкурентних відносин між популяціями рослин природної флори та культивованими видами рослин. Тому конкуренція між природними представниками різних життєвих форм - травами, кущами, деревами, яка стримувалася при сільськогосподарському використанні угідь, значно посилюється $[11,18]$. Ми з'ясували, що на перших етапах формування перелогів на поозер'ї відбуваються відновні сукцесії переважно трав'яної рослинності. Так, на минулорічних полях, що були під зерновими, домінантами природної рослинності переважно виступають злинка канадська (Solidago canadensis L.) та метлюг звичайний (Apera spi$c a$-venti (L.) P.B.). Проте ці однорічники швидко, впродовж двох-трьох років, витісняються багаторічниками, зокрема пирієм повзучим (Elytrigia repens (L.) Desv.) та щавлем горобиним (Rumex acetosella L.). Після вирощування просапних культур домінантом (деколи до $90 \%$ вкриття) травостою на перелогах буває цмін пісковий (Helichrisum arenarium (L.) DC.). Якщо перелоги використовують для випасу худоби, то в процесі сукцесій однорічні трави на них витісняються такими багаторічниками, як пирій повзучий, очиток їдкий (Sedum acre L.), енотера дворічна (Oenotera biennis L.), дивина ведмежа (Verbascunm thapsus L.) та дивина чорна (V. nigrum L.). Стадія цих багаторічників $є$ довготривалою, до 5-8 років. Поява дерев на випасах та формуван- ня рідколісся відбувається вже на пізніших стадіях їх заростання, бо стримується внаслідок інтенсивного випасання худоби. Характер змін трав'яної рослинності після припинення орного використання земель (на прикладі модельного полігону "Колеса") відображає такий сукцесійний ряд:

- злинка канадська + метлюг звичайний (фото $1, a)$;

- пирій повзучий + щавель горобиний +;

- пирій повзучий + дивина ведмежа + очиток їдкий + енотера дворічна + жабник польовий (Filago arvensis L.) (фото 1,б);

- береза повисла + сосна звичайна + груша.
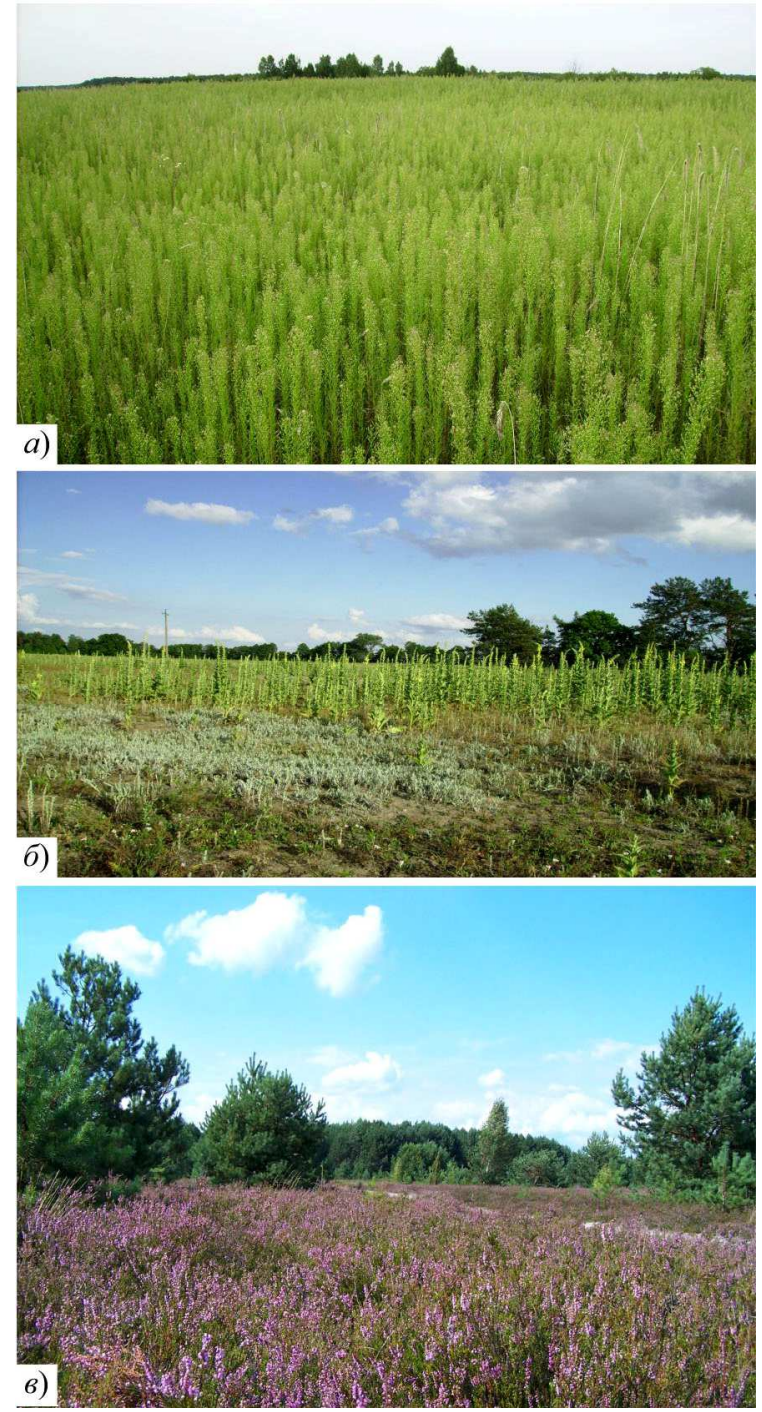

Фото 1. Домінування злинки канадської та метлюга на колишніх полях $(a)$, сукцесійна стадія багаторічників на колишнх полях (б), вересовища як рідкісні оселища та їх заліснення сосною (в)

Разом 3 тим швидкість сильватизації постаграрних екосистем у межах української території ТБР проявляється по-різному, і зумовлюється, зокрема, й наявністю та близькістю джерел обнасінення. На старооранках цей процес може бути як довготривалим, у вигляді декількох стадій розвитку трав'яної рослинності та утворення деревостану, так і швидким. Зокрема, відзначено прояви швидкого заліснення недавніх перелогів, що межують зі стіною лісу. У таких випадках спостерігається формування високоповнотних березово-соснових деревостанів і посилений їх ріст у висоту, а формування трав'яної рослинності під ними сповільнене. Заліснення ж осушених боліт на поозер'ї $є$ процесом поступовим і довготривалим, проходить через стадію рідколісся та за 
багаторазовості занесення діаспор дерев, що відображається віком особин берези і сосни (від 3-4-річок до 10-12-річок) та значним розмахом їх висот (від 0,4 до $3 \mathrm{~m})$.

У процесі сильватизації відбуваються значні зміни морфологічних і хімічних параметрів грунтів на колишніх угіддях $[2,10,18]$. Було охарактеризовано і порівняно такі типи грунтів:

- осушені торфово-болотні і торфові (низинні торфовища) грунти заплави (полігони Кулевицьке та Дубовець);

- дерново-підзолисті грунти (полігон Макошин);

- дернові грунти (окраїна болота Рипицьке);

- торфово-болотні грунти (полігон Рипицьке).

Основною відмінністю в морфологічній будові грунтів на заліснених і незаліснених ділянках є формування шару лісової підстилки на сильватизованих ділянках, в якому, окрім трав'яної повсті, присутній опад дерев. У високоповнотних соснових жердняках горизонт $\mathrm{H}_{0}$ повністю сформований опадом хвої. Значно більшою на сильватизованих ділянках $є$ пронизаність верхніх горизонтів коренями рослин, що покращує режим аерації i робить їх рихлішими; меншою є й вологість цих горизонтів. Відсутність суцільного задерніння, краща аерація і менша вологість осушених торфових грунтів стимулює процеси мінералізації торфу (його "спрацювання"), що призводить до зменшення його потужності, тоді як суцільне задерніння певною мірою "консервує" торф. У дерново-підзолистих та дернових грунтах зменшується потужність гумусовмісних горизонтів та відбувається поступова диференціація орного змішаного шару грунту на горизонти.

Зміни в хімічному складі торфово-болотних грунтів осушених торфовищ та їх зольності під впливом формування молодняка берези повислої розглянемо на прикладі аналізів погоризонтно відібраних зразків грунту на пробній площі ПП1-06 (осушене торфовище) та на відповідній їй тестовій ділянці ТД1-06 (поле). 3'ясовано, що розподіл доступного азоту $\left(\mathrm{N}-\mathrm{NH}_{4}\right)$ по глибині профілю показує рівномірне спадання його кількості зі збільшенням глибини профілю. Відзначено меншу його кількість під залісненими ділянками (до 32,50 мг/кг), ніж під діючим сінокосом (до 43,20 мг/кг). Це свідчить про інтенсивніше споживання вільного азоту деревостаном.

Розподіл $\mathrm{K}_{2} \mathrm{O}$ показує, що в торфово-болотних грунтах накопичення калію спостерігається найбільше у верхніх горизонтах профілю і зменшується з глибиною. Під залісненими ділянками кількість калію $є$ меншою (до 180,3 мг/кг), ніж під незалісненими (до 220,0 мг/кг). Кількість $\mathrm{P}_{2} \mathrm{O}_{5} \epsilon$ найбільшою у вмивному горизонті (до 70 мг/кг, але під молодняками чіткий вплив сильватизації на цей показник не простежується.

Зроблено висновок, що заліснення в умовах поозер'я сприяє зменшенню кислотності торфових грунтів внаслідок посилення їх аерації і збільшення транспірації вологи 3 верхнього шару грунту. Відбувається також зменшення вмісту азоту в грунтах під деревостанами, які формуються.

Спонтанне формування лісу у постаграрних екосистемах Шацького поозер'я деколи потребує антропогенного регулювання з природоохоронних позицій. Так, сильватизація піщаних грив, як колишніх орних земель, зумовлює витіснення сосною та березою таких своєрідних рослинних угруповань, як вересовища (фото 1,6), що підлягають охороні за NATURA 2000 як оселища типу 2310 - сухі пустища з Calluna vulgaris L. Поява лісу на болотах призводить до деградації локалітетів рідкісних видів гігрофітів, зокрема берези низької (Betula humilis Shrank), деяких осок та орхідних, що варто враховувати у природоохоронній діяльності Шацького національного природного парку як основної адміністративно-природоохоронної територіальної структури у межах української частини ТБР "Західне Полісся".

\section{Висновок}

Аналіз літератури свідчить про важливість вивчення проблеми заліснення колишніх сільськогосподарських угідь на світовому рівні. Збільшення площ перелогів та розвиток процесів їх сильватизації відбувається і в Україні. Посилення процесів сильватизації колишніх сільськогосподарських угідь у межах української частини ТБР "Західне Полісся", яка територіально охоплює регіон Шацького поозер'я, зумовлене передусім соціально-економічними причинами. Разом з тим, заліснення земель відбувається відповідно до еколого-біотичної специфіки регіону і $є$ історично зумовленим. Знання перебігу сильватизації постаграрних екосистем у межах ТБР $є$ важливим для вирішення низки природоохоронних проблем.

Припинення використання сільськогосподарських угідь 3 біотичних позицій означає зняття щорічного трансформаційного антропогенного впливу на функціонування угідь як екосистем чи то у вигляді оранки, чи сінокосіння, чи випасу. Зникнення такого регулятора конкурентних відносин між популяціями рослин природної флори та культивованими видами сільськогосподарських культур також є однією 3 причин посилення сильватизації постаграрних екосистем.

У процесах заліснення основну участь беруть анемохорні види рослин, зокрема сосна та береза, менше осика, а також кущові види верб. Анемохорні трави також $є$ основними компонентами на початкових етапах відновних сукцесій на перелогах, особливо такі, як злинка канадська та метлюг, онагра дворічна та дивина ведмежа.

На підставі вивчення динаміки морфологічних ознак грунтів зроблено висновок, що сільськогосподарське використання осушених боліт, яке супроводжується задернінням (сінокосіння, випас худоби), сприяло консервації шару торфу і стримувало його мінералізацію, тоді як процеси сильватизації пришвидшують спрацювання торфу і зменшують потужність його шару. За відсутності антропогенного впливу у вигляді сінокосіння чи випасу формування лісу пришвидшується. Утворення лісу може відбуватися не тільки шляхом лісовідтворення (як лісовідновлення та лісорозведення), але й шляхом сильватизації перелогів та осушених боліт. Для збереження локалітетів рідкісних видів рослин у процеci спонтанного заліснення постаграрних екосистем (наприклад, берези низької, орхідних) та рослинних угруповань (зокрема вересовищ) у межах української частини ТБР необхідне застосування активних заходів 3 їх охорони шляхом вилучення 3 таких ділянок сосни та берези.

\section{References}

1. Alekhina, O. V., et. al. (2014). Evolution of the state of ecosystems of the UNESCO "Vioreserve Shatsky" in the 
conditions of intensification of influence of climatic changes and anthropogenic factors. Nature of Western Polissya and adjacent territories: coll. Science. works for ed. F. V. Zuzuka, 11, (pp. 101108). Lutsk. [In Ukrainian].

2. Gavrilov, S. O. (2009). Dynamics of agrophysical indicators of soil with long-term withdrawal from cultivation. Bulletin of ZhNAU, 2, 125-130. [In Ukrainian].

3. Gorshenin, N. M., \& Shvydenko, A. I. (1977). Forestry: textbook. Lvov: ed. association "Vishcha school", 304 p. [In Russian].

4. Kaurichev, I. S. (Ed.). (1975). Soil Science. (2nd ed. add. and revised). Moscow: Kolos, 496 p. [In Russian].

5. Korchagin, A. A. (1976). The structure of plant communities. Field geobotany, T. 5. Leningrad: Science, Leningrad branch, 320 p. [In Russian].

6. Korus, M. M., \& Yashchenko, P. T. (2009). Silvatization of agricultural ecosystems of Shatsk Lakeland as a manifestation of their renaturalization. Scientific Bulletin of Volyn National University named after Lesya Ukrainka. Biological Sciences, 2(2), 64-71. Lutsk: Tower. [In Ukrainian].

7. Luri, D. I., et. al. (2010). Dynamics of agricultural lands of Russia in the twentieth century and post-agronomic restoration of vegetation and soils. Moscow: GEOS, 416 p. [In Russian].

8. Matyunin, S., et. al. (2009). Three Polesie: a joint strategy for the protection and ecological use of the natural heritage of the Belarusian-Polish-Ukrainian border. Brest, 86 p. [In Ukrainian].

9. Nayda, V. S. (2008). Shatsk Biosphere Reserve is a Ukrainian component of the trilateral biosphere reserve "Western Polissya". Creation of a transboundary biosphere reserve and a regional ecological network in Polissya. Kyiv, 25-43. [In Ukrainian].

10. Parchuk, G., Yashchenko, P., \& Goryn, A. (2015). Natural resources, organization of zonation of the Shatskyi Biosphere Reserve. 15 lat Poleskiego Parku Narodowego. Monographia, (pp. 83-93). Warsaw, Lublin, Urszulin, 360 p.

11. Pashkevich, N. A., \& Gavrilov, S. O., Zuzuka, F. V. (Ed.). (2012). Transformation of vegetation of fallow lands on the territory of Shatsk National Nature Park. Nature of Western Polissya and adjacent territories: coll, 9, (pp. 139-142). Lutsk: Volyn. nat. Univ. Lesya Ukrainka. [In Ukrainian].

12. Shpakivskaya, I. M. (2016). Agrogenic transformation of morphological, physicochemical and ecophysiological properties of sod-podzolic soils of Volyn Polesie (Ukraine). Problems of rational use of natural resources and sustainable development of Polesie: collection of reports. int. scientific conf., 2, (pp. 80-83). Minsk: Belarusian Science. [In Russian].

13. Sotnik, L. P., \& Popovich, S. Yu. (2012). Forest vegetation of the Biosphere Reserve Shatsky. Kyiv: TsP COMPRINT, 136 p. [In Ukrainian]

14. Telesnina, V. M. (2015). Post-agrogenic dinamics of vegetation and soil properties during demutation succession in the southern taiga. Forestry, 4, 192-205. [In Russian].

15. Vorobiev, D. V. (1967). Methodology for forest typological research. (2nd ed. add. and revised). Kiev: Harvest, 383 p. [In Russian].

16. Yashchenko, P. T., \& Nadorozhnyak, O. Ya. (2003). Silvatization as a process and factor of renaturalization of natural ecosystems of Western Polissya. Forestry research in Ukraine (IX Pogrebnyakov readings): a collection of scientific and technical works. Lviv: Scientific Bulletin of UNFU, 13(3), 171-176. [In Ukrainian].

17. Yashchenko, P. T., Gorun, A. A., Mateychik, V. I., \& Tkachuk, O. V. (2003). Peculiarities of spontaneous afforestation of the upper reaches of the Pripyat river valley. Forestry research in Ukraine (IX Pogrebnyakov readings: a collection of scientific and technical works. Scientific Bulletin of UNFU, 13(3), 257-263. [In Ukrainian].

18. Yashchenko, P., Korus, M., Mateychik, V., \& Turych, V. (2018). Manifestations of silvatization of ecosystems of Shatsk National Nature Park. Status and biodiversity of ecosystems of Shatsk National Nature Park and other protected areas. Shatsk: materials of sciences. conf. Lviv: Spolom,122-131. [In Ukrainian].

19. Yashchenko, P., Korus, M., Mateychik, V., \& Turych, V. (2019). Peculiarities of silvatization of post-agrarian ecosystems of the Ukrainian part of the international Polish-Belarusian-Ukrainian biosphere reserve "Western Polissya". Actual problems of environmental protection of Ukrainian-Polish border areas: thesis add. international Science. practice. conf, (pp. 82-83), Lviv-Ivano-Frankove, October 23-25. Lviv: PAIS. [In Ukrainian].

20. Yurchuk, P. V., et. al. (2014). Rarities of biota of the Shchak National Nature Park (distribution, habitats, threats and conservation). Kyiv: TsP KOMPRINT, 111 p.

N. N. Korus ${ }^{1}$, P. T. Yashchenko ${ }^{2}$

${ }^{1}$ G. V. Karpenko Institute of Physics and Mechanics, National Academy of Sciences of Ukraine, Lviv, Ukraine ${ }^{2}$ Institute of Carpathian of Ecology, National Academy of Sciences of Ukraine, Lviv, Ukraine

\section{CONDITION AND APPEARANCE OF SILVATIZATION OF POST-AGRARIAN ECOSYSTEMS OF UKRAINIAN PART OF THE TRANSBOUNDARY BIOSPHERE RESERVE "WESTERN POLESIE"}

The conditionality of spontaneous afforestation (silvatization) of former agricultural lands in the Ukrainian part of the Transboundary Biosphere Reserve "Western Polissya" (TBR), which is territorially represented by the region of Shatsk Lakeland, is characterized. The Shatsk National Nature Park has been operating here since 1983, which in 2002 was granted the status of an international biosphere reserve (BR) and included in the UNESCO world network of biosphere reserves as the Shatsk BR. Since 2012, this reserve is a part of the Belarusian-Polish-Ukrainian TBR. Environmental and recreational forms of land use in the Lakeland have become dominant, agricultural land use has decreased. It is shown that the intensification of the processes of silvatization of post-agrarian ecosystems is due primarily to socio-economic reasons. With the change of the socio-political system of Ukraine in the $1990 \mathrm{~s}$, new economic relations emerged, in particular, the nature of land use changed. After the liquidation of collective farms, many arable lands in the region fell out of intensive economic use, significantly increased the area of fallow land and waste, which began to spontaneously afforest. Hay and pasture use of swamps and sown meadows formed on drained swamps ceased, which led to the development of restorative successions of natural vegetation on the former lands. Silvatization has become an important environmental problem due to significant changes in the vegetation structure of Shatsk Lakeland. Manifestations of regenerative successions of vegetation after cessation of arable and haymaking use of lands are considered. It is shown that afforestation occurs in accordance with the ecological and biotic conditions of the region and the historical features of land use. There is a renaturalization of vegetation on gryland, but there is a further transformation of meadows and swamps, which were used as hayfields and pastures. Sylvatization manifests itself as the formation of either pine sparse forest or dense birch forest. The largest amount of natural regeneration of birch - up to 75 thousand per 1 ha - was observed in the former old plows. The formation of a closed stand on old plows can occur for 10-12 years, especially with the close location of the forest wall. After afforestation, the physicochemical parameters of soils change, in particular, the acidity of peat soils decreases and the nitrogen content in them decreases. Emphasis is placed on the expediency of active conservation of localities of rare species plants and plant communities in the process of spontaneous afforestation of post-agrarian ecosystems within the Ukrainian part of the TBR.

Keywords: Shatsk Lakeland; fallows; heathers; introduction and distribution of seeds; forest wall. 